\section{MANAGEMENT COMMITTEE}

\section{NZIE CONFERENCE}

The New Zealand Institution of Engineers Annual Conference will be held in Wellington on 12-17 February, 1979. The Society, along with other technical groups (e.g. Water Building Services, Chemical Engineering, etc.) will hold a day long technical session on Tuesday 13.

Although the detailed programme for the Society's technical session has not been finalised it is likely to include morning sessions on the new material codes (concrete, steel and timber) and afternoon sessions on base-isolated structures and designers experiences with the new loadings code NZS 4203. Formal presentation by the codes' authors will be brief and general discussion encouraged.

A general meeting of the Society will be convened about $5.00 \mathrm{p} . \mathrm{m}$. and this will be followed by a social gathering. The A.G.M. of the Society will be held at the South Pacific Regional Conference and not (as reported in the last Bulletin) at the NZIE Conference.

\section{AWARDS}

The annual award of the Society is made to the authnr(s) presenting the best paper during the three years ending June 30 preceeding the date of the award. Ncminations of papers for the 1978 Award should be in the hands of the Secretary by 30 November, 1978 .

Details of the Award were given in the Bulletin, Vol. 10, No. 2 (June 1977) but can also be obtained from the Secretary.

\section{RECNNNAISANCE TEAMS}

Immediately after a damaging earthquake in New Zealand the Society will send a team of experienced observers into the field to ensure that as much information is obtained on all aspects of earthquake damage and to record detailed information which might be lost in reconstruction works.

The pool of possibie team members contains 25 names. It is thought that an optimum size for the pool is about 30 to 35 .

If you wish to put your name forward for consideration as a member of the pool please write to the Team Organiser (Mr. J. P. Hollings) at P.O. Box 3942, Wellington, giving professional qualifications, details, if any, of previous reconnaisance experience, present occupations and fields of special knowledge. All applications will be subject to review by the Management Committee.

\section{WORKSHOPS}

Workshops for the Seismic Design of Ductile Moment Resisting R.C. Frames will be held at Auckland University from the l3th to 15th November, 1978 and at Victoria University of Wellington from 28th February to 2nd March, 1979. The date has not been finalised for the Christchurch workshop.

Participation will be limited to 30 at each workshop and enrollments may be made to the Secretary of the Society, P.O. Box 243, Wellington. Applications should include the $\$ 50$ course fee. Separate brochures will also be distributed by the Extension Studies Department of each University.

The Workshops will be based on the series of papers published in the Bulletin and will cover the analysis, desjgn and detailing of a typical medium rise framed building. Participants should be familiar with the papers already published and will be expected to do calculations and sketches in the course of the workshop.

\section{NOTICES}

\section{BRIDGE SEMINAR REMINDER}

A seminar on bridge design and research will be held at Auckland University on 16-18 November, 1978. The seminar is intended to review all research on highway structures undertaken on behalf of the structures Committee of the Road Research Committee in the four years since the last such seminar in 1974. Topics covered will fall into three broad areas of interest; bridge superstructure behaviour, bridge substructure and foundation behaviour and scour at bridge piers and waterway design.

Contact the Centre of Continuing Education, University of Auckland, Private Bag, Auckland for further details. (Full registration $\$ 50$, graduates $\$ 35.00$, students $\$ 10.00$.

\section{POWER LIFT RULES 1978}

Part 1 (General Requirements) and Part 2 (Electric Lifts) of the revised draft power lift rules have recently been circulated for comment by the Marine Division of the Ministry of Transport. The rules include provisions for the seismic design of lifts. Discussion was to close on 30 September, 1978 but this date has now been extended to 21 December, 1978.

\section{REVIEWS}

\section{SEISMIC RISKS TO LINEAR STRUCTURES}

Most studies of earthquake risk concern themselves with structures of comparatively limited size - buildings, bridges, dams, and the like - yet modern communities are at least equally dependent upon roads, railways, power lines, and pipelines, which have a considerable linear extent, and whose failure at any point can have repercussions in widely distant places. Two recent papers have examined the implications of this $(1,2)$.

Hakuno considers that studies of past earthquakes establish that these "life-line networks" are more readily damaged than buildings, and that the effects of the damage are often long lasting. He instances the earthquake near Udine in northern Italy in 1976, where Udine itself lay outside the area of severe damage, suffering only the loss of roof-tiles and the like, but was crippled by complete failure of electric 
power for several days, and the interruption of railway services for a month.

The basic characteristics of these vulnerable services are their length and their narrowness. A satisfactory approximation of their behaviour can be made by assuming them to be composed of a suitable number of discontinuous elements. Taleb-Agha's analysis is the more mathematically elaborate, using topological transforms of the more complex networks and leading to a computer programme that can be applied to complete or partial network failure arising from a given set of earthquake origins or fault movements. This programme he uses to analyse the risks to the system of major highways near Boston.

Hakuno's treatment is simpler. He distinguishes between "series systems" such as railways, water supply lines, and river embankments; and "mixed systems" such as roads, electricity distribution, and telephone networks, in which the service can be wholly or partly maintained through undamaged branches of the net.

If a series structure consists of $n$ units, each statistically independent and having a damage probability $p$, the total damage probability of the system

$p_{r}=1-(1-p)^{n}$.

The probability $p$ of damage to the individual units depends on their nature as well as upon their length. A local foundation settlement of $10 \mathrm{~cm}$ will seriously paralyse a railway, but be of only minor consequence to a road. Most linear structures, however, are disrupted by comparatively slight

failures, and the probability of disruption increases sharply with the number of elements of which they are composed. In systems with a redundancy $m$, the probability of total disruption falls to

$\mathrm{p}_{\mathrm{T}}=\left[1-(1-\mathrm{p})^{\mathrm{n}}\right]^{\mathrm{m}}$

Hakuno considers the probability of damage to a water pipeline, based on a rate of 0.22 failures per kilometre experienced in the Kwanto earthquake of 1923. Assuming a unit length of 100 metres, based upon the frequency of observed breaks, the probability of a $10 \mathrm{~km}$ pipeline failing is 0.892 , or almost a certainty. A single parallel line would reduce the probability to 0.796 . In many situations, however, the substitution of parallel for simple systems would be prohibitively expensive, and reinforcement of weak elements of the linear structure preferable. Further analysis of the nature and incidence of damage to linear structures is clearly desirable.

$$
\text { G.A.E. }
$$

\section{References}

1. Hakuno, M., 1977, "Damage Probability of Line Structures Due to an Earthquake". Bull. Eq. Res. Inst. Tokyo. 52. 373-8.

2. Taleb-Agha, G., 1977, "Seismic Risk Analysis of Lifeline Networks". Bull. Seismol. Soc. Amer. 67, 1625-45.

THE KHURGU (IRAN) EARTHQUAKE OF 21 MARCH, 1977

A shallow magnitude $7.0\left(\mathrm{M}_{\mathrm{S}}\right)$ earthquake occurred about $40 \mathrm{~km}$ north of Bandar Abbas in the seismically active region of South Iran on 21 March, 1977. A foreshock about 15 seconds prior to the main event brought many people out of their dwellings and major loss of life was avoided (152 deaths).

The earthquake was characterised by a restricted epicentral region in which there appeared to be evidence of intense but not prolonged shaking. No surface faulting was observed.

Many modern buildings in Bandar Abbas were shaken to the verge of structural damage and the processing and publication of the strong-motion records obtained there are awaited with interest.

(Reference: Khurgu (North Bandar Abbas, Iran) Earthquake of March 21, 1977: A Preliminary Field Report and a Seismotectonic Discussion, by $M$. Berberian and $D$. Papastamation, Bulletin of the Seismological Society of America (BSSA), Vol. 68, No. 2, p.411-428, April 1978.)

\section{SEISMICITY OF THE MIDDLE EAST}

This review paper contains a figure illustrating earthquake activity in the Middle East in the last 19 centuries, a listing of destructive earthquakes since the year 1900, and a figure illustrating the location of surface faulting associated with earthquakes in the last 7 centuries.

(Reference: Middle East - A Reappraisal of the Seismicity, by N. N. Ambraseys in Journal of Engineering Geology, Vol. 11 , p.19-32, 1978 .

\section{MAGNITUDE OF THE 1952 KERN COUNTY EARTHQUAKE}

The July 21, 1952 Kern County (California) earthquake is the largest earthquake in the United States since 1906. Strong-motions recorded during the earthquake (e.g. at Taft) have played an important role in earthquake engineering research, in the formulation of current seismic loading and design provisions in many countries, and in providing important data for the study of the attenuation of shaking with distance in large earthquakes.

It is therefore of considerable interest that a recent review of data from the seismographs for this earthquake suggests a local magnitude of 7.2 which is somewhat lower than the normally quoted (surface wave) magnitude of 7.7 determined by Gutenburg.

(Reference: The Local Magnitude $M_{L}$ of the Kern County Earthquake of July 21, 1952, by B. A. Bolt, in B.S.S.A., Vol. 68, No. 2, p.513-515, April 1978.

\section{RECENT EARTHQUAKE ENGINEERING RESEARCH IN JAPAN}

The 1976 edition of this series contains discussion of a wide variety of current research programmes in Japan including strong-motion networks, tsunami warning services, earthquake prediction, liquefaction studies, soil-structure interaction studies, and articles on bridge and structural design for earthquake.

(Reference: Some Recent Earthquake 